\title{
The Implementation of Human Rights Fulfillment as an Effort to Strengthen Positive Peace in Indonesia
}

\author{
Siti Maizul Habibah* \\ Pancasila and Civic Education \\ Department \\ Faculty of Law and Social Sciences, \\ Universitas Negeri Surabaya \\ Surabaya, East Java, Indonesia \\ sitihabibah@unesa.ac.id
}

\author{
Iman Pasu Purba \\ Pancasila and Civic Education \\ Department \\ Faculty of Law and Social Sciences, \\ Universitas Negeri Surabaya \\ Surabaya, East Java, Indonesia \\ imanpurba@unesa.ac.id
}

\author{
Rahmanu Wijaya \\ Pancasila and Civic Education \\ Department \\ Faculty of Law and Social Sciences, \\ Universitas Negeri Surabaya \\ Surabaya, East Java, Indonesia \\ rahamanuwijaya@unesa.ac.id
}

\begin{abstract}
This article is motivated by the State of Indonesia is an archipelagic country consisting of various customs and cultures. This diversity fosters the values of diversity that exist in the community where they should respect the values of diversity. This diversity consists of culture which will givemeaning to cultural diversity. This certainly provides these values of diversity that should emerge and be valued in social life in all aspects of life.Social life is impossible to erase conflict from this world. Both intrapersonal, interpersonal, and inter-group conflicts are constitutive parts of human history. This cannot be resolved only by coercive rules or by the reprisal of violent weapons, but by other more dignified ways of raising awareness among citizens of the importance of coexistence that we can do through peace education. The purpose of writing this article is to provide an overview of the importance of peace education to all Indonesian people both through education levels and education and training outside of education. With the education of diversity peace that occurs in Indonesia, this can be called beauty not as a trigger for intrapersonal, interpersonal, or inter-group conflict. Based on information conveyed through the media, both electronic and mass progress, appreciating diversity illustrates not a few causes of conflict. Conflict is a part of human life that will not disappear from history. Ethnic and racial differences coupled with religious differences are a more powerful cause for division among groups in society. The method used in writing this scientific article is descriptive qualitative and data collection in a literature review that generates ideas about efforts to strengthen Positive Peace that are often overlooked. First, efforts to prevent early social conflict need to be done. Second, conflict mapping can help graphically illustrate conflict which is useful for seeing the overall conflict actors and their relationships. Third, it is necessary to formulate a system of continuous monitoring of the regions and communities, which are prone to conflict.
\end{abstract}

Keywords: Positive Peace, diversity values, conflict, national integration.

\section{INTRODUCTION}

Indonesia is an archipelago which currently has 1,300 large and small islands, with a population of more than 200 million people, consisting of 300 tribes and using nearly 200 different languages, and adopting different religions and beliefs, such as Islam, Catholicism, Protestant Christianity,
Hinduism, Buddhism, Confucianism and various schools of belief. According to this fact, of course, Indonesia needs a strategy and the ability to manage such diversity. The true diversity of gifts that need to be maintained and managed so as not to turn into conflict with violent conflict. The conflict that was warm the other day in Papua. The conflict is only one of several conflicts that are based on ethnic, religious, and racial differences. This kind of SARA conflict cannot be avoided in this country, because Indonesia is given the gift of ethnic, religious, ethnic, and racial diversity.

Based on the understanding of the conflict process above shows that the Indonesian nation has a low awareness in understanding the diversity that exists. The lack of awareness is the main trigger for the occurrence of gross human rights violations that often occur now. Human Rights (HAM) is a right inherent in every human being from the beginning of birth that is valid for life and cannot be contested by anyone. As good citizens we must uphold the value of human rights without discriminating against status, class, descent, position, and so forth. Violating a person's human rights is contrary to the laws in force in Indonesia.

To minimize protracted human rights violations, it is necessary to have detailed and comprehensive knowledge related to human rights to the whole community. Considering that the people of Indonesia do not all aware and having knowledge of the limits of human rights violations. Knowing human rights in detail, human rights formulas are needed in conditions of the diverse and diverse Indonesian people, ethnicity, religion, race, and ethnicity, although the UN has issued a declaration of human rights since December 10, 1948.

Efforts that lead to associative actions such as the establishment of peaceful values through education are needs that must be actualized immediately. Starting a peaceful life is with a peace education program that is channeled with conflict resolution and multicultural understanding, including an activity based on the ability of individuals in opinion. Trying to understand and understand others and the things that underlie their thinking will be useful as a tool that can be used to solve problems, for example; racism, discrimination or disturbing others [1] 
Diversity in education exists because education cannot be separated from the context of society. Children as the center of attention for education, which are often forgotten, are part of their social context. They have different social and cultural contexts. Therefore, it is the reason that it is important to get multicultural education so that they can adjust well. [2]

Based on the presentation is mentioned above, it can be concluded that knowledge about fulfilling human rights and strengthen positive peace in Indonesia needs to be implemented.

\section{METHOD}

In this study using qualitative research methodologies in collecting data prioritizing community interviews (Moleong, 2009). The focus of research is concerning public services. Considering this research was conducted at the Airmadidi District Office of North Minahasa Regency, the research informants were employees who held structural, non-structural and community. Data collection is done by in-depth interviews (in-depth interviews) to each informant. The results of data collection are reduced and then summarized data is found to be relevant to the problem and research objectives. (Sugiyono, 2008). Data analysis techniques in qualitative research use an interactive analysis model whose data results are presented in narrative form.

\section{RESUlts AND DisCUSSION}

\section{A. Portrait of Fulfillment of Human Rights in Indonesia}

Cases of human rights violations that recently occurred in Indonesia greatly affect the pride and dignity of the Indonesian people, affect the nation's future and affect the fading of national identity. This shows that human rights violations are not only committed by the state to its people but also by the people to the people (human rights violations horizontally) [3]. In 2019 the case of human rights violations conceptually conveyed above occurred in the racism of Papuan people which caused horizontal human rights violations to occur. This happens due to the unconsciousness of the community in the diversity that occurs in the nation.

In facing the current conditions in the city of Ambon after the conflict the ex-combatants responded with caution. so that the spark that emerges is a form of peaceful attitudes such as feelings, words, and actions solely for the purpose the harmony [4]. Violations of human rights that are discriminatory or discriminating between men and women often occur. Likewise, human rights violations caused by issues of ethnicity, religion, race, and intergroup (SARA). Various human rights instruments found in Indonesia have not been able to protect their citizens from human rights violations even though the United Nations has declared human rights which in essence asserts that every person is born with the same right to freedom and dignity without distinguishing race, color, religious and political beliefs, language and gender.

The Law of the Republic of Indonesia No. 39 concerning Human Rights, 2004 concerning the Medium-Term Development Program addresses three issues of efforts to uphold human rights in Indonesia, namely First, there are still many human rights violations. Human rights violations still occur and are committed by groups or groups or individuals against groups or groups and other people. Therefore, it is very important to see a variety of human rights violations committed. Responding to problems that occur related to human rights violations committed by groups shows that the group or organization that is formed in this country is not yet solid in the context of resolving the differences.

In the social context of the problem caused by certain groups is a problem of the government to resolve the problem both consensus and peace and the common vision and mission of the state to bring about positive peace between groups. Efforts can be made, for example, to minimize the news that HOAX can trigger disputes.

Second is the problem of impunity, the number of human rights violations that are not responsible, and cannot be punished (impunity). This impunity has been widespread and almost occurred in every case of human rights violations. For example, cases of human rights violations in the Trisakti and Semanggi tragedies. This is very worrying because it will weaken the position of victims of human rights violations. The second problematic shows that there are problems that linking toPolicyMakers with the community. Based on this issue, there should be a concept of fulfilling the rights of victims. If the victim of this violation of rights is left then the government will become an institution that violates human rights. This is because victims of human rights violations have the same legal and social rights.

The Third is the malfunctioning of state institutions which authorized and obliged to uphold human rights. This happened in all existing institutions, starting from the National Commission (Komnas HAM), the Attorney General's Office, the court, the Ministry of Law and Human Rights, the DPR-RI, to the Presidential Institution. This agency takes the obligation to make sure that human rights will be fulfilled in Indonesia. If an agency is hampered by its role, especially in the context of human rights, then the implementation of human rights fulfillment to create positive peace in a country that has diversity like Indonesia will not be achieved. If positive peace is not realized then it will have an impact on the high number of conflicts that occur in the future. In reduce the occurrence of conflicts related to human rights, the formula for the fulfillment of human rights can be carried out both in the scope of multicultural education in schools as well as advertisements about positive peace in electronic and digital media. The goal is knowledge about human rights not only consumed by highly educated people but human rights can be consumed by all people.

Finally, the current attitude of society that is indifferent to what is happening around them, with the argument that they do not want to interfere in other people's business, fading a sense of togetherness and the prominence of individual feelings makes the community less sensitive to the crimes that occur around them. Assuming that as long as the crime did not occur to his family is not his responsibility. Yet if everyone has empathy, humanity must help protect others, no matter who the identity or who that person is. Based on the above problems it can be concluded that the mindset of Indonesian people to address human rights is by carrying out individual attitudes as a powerful way to minimize friction with the interests of others. The mindset 
like the case above if studying the concept of fulfilling human rights from a social context is certainly wrong, it is assumed that humans are social creatures who need interaction with other humans.

Whereas the problem of fulfilling human rights that often occurs now is the attitude of intolerance over diversity that occurs is a trigger for human rights violations. If the attitude of ignorance is used as a solution to minimize this world seems dead because there is no interaction between humans. Fulfillment of human rights does not mean individualist but every human being is aware that the surroundings have differences in terms of economics, religion, character, and personality.

Based on the problems that occur, it can be concluded that efforts to promote, respect and uphold (fulfillment of human rights) in Indonesia consist of efforts to solve problems and protect human rights, formulate human rights action frameworks, and develop and empower human rights institutions. As well as community participation to be aware in protecting and respecting human rights during the times, the Government's Efforts to Resolve Problems and Protect Human Rights have tried to establish the National Commission on Human Rights (Komnas HAM) in 1993; Enactment of Law of the Republic of Indonesia Number 39 of 1999 concerning Human Rights (HAM); Enforcement of the Law of the Republic of Indonesia Number 26 concerning the Court of Human Rights (HAM).

Indeed our country is a country that upholds human rights. This is in line with the ideology adopted by our nation, Pancasila. Pancasila ideology has a philosophy that can be used as a reference or benchmark for how Indonesian people behave in interactions with other communities. this is used as an embodiment of the 3rd precept, namely the unity of Indonesia. The meaning contained in the precepts is that people are prohibited from insulting, discriminating, discriminating, and abusing but Indonesian people must be able to respect, respect, tolerate, and behave fairly. Thus every community will realize and independently minimize and even prevent human rights violations from happening.

\section{B. Implementation of Human Rights Fulfillment as Efforts to Strengthen Positive Peace In Indonesia}

Positive Peace is a situation where there is no violence either direct violence, structural violence, or cultural violence or the creation of social justice and the formation of an atmosphere of harmony [5]. Positive peace is reflected when there are no violations of humanity that occur in others [6]. Yet the fact is that in this decade human rights violations are still rife. Humans are subjects who must receive protection and guarantee for human rights. Because humans as God's creatures have high dignity, human rights exist and are inherent in every human being. Therefore, it is universal, meaning that it applies everywhere and for anyone and cannot be taken by anyone. These rights are equal for both men and women.

Peace education is one of the learning efforts that can contribute and be able to create better citizens in the world. The process of transformation is the same, namely by instilling a philosophy that supports and teaches without violence, which also means protecting the environment and one's own life as humans. Peace education provides an alternative by teaching students how violence can occur and informing students about critical issues of peace education namely peacekeeping, creating peace (peacemaking), and building peace [7].

Activities related to the existence of peace education should not be limited to schools or educational institutions. This issue should be understood in a broader perspective both in national and international dimensions. Together with the efforts made by school staff, the community and most important is that families should join one another for making peace permanent and effective.

Besides the role of the education world, the role of the family in providing a complete understanding of the concepts, meaning, and application of peace is very significant and can be the background or foundation of a belief in the principle of peace in the hearts of our children. This becomes the basic capital of a small-scale behavioral value order at the lowest level, namely self, and family. Individual education starts with the family and is continued by the school and social environment. The process of gaining important knowledge, skills, and good behavior starts from the family until basic education and is continued by the media and the social environment. All knowledge, skills, and behaviors that are directly acquired will affect the way of viewing life. In other words, beliefs and values obtained in each phase of learning not only shape a person's character but also contribute in makethe better world.

The community lacks guidance in openness in finding joint solutions and is weak in analyzing external provocation or certain interests, due to the weak level of education and welfare of the community. This is compounded by the attitude of conflict actors who should refrain themselves from being consumed by issues that can escalate conflict and make matters worse. The community should understand the conflict so it is not used

\section{CONCLUSIONS AND SUGGESTIONS}

\section{A. Conclusion}

First, There are still crucial problems in the life of the nation and state, including; First, there are still many human rights violations. Second is the problem of impunity, the number of human rights violations that are not responsible, and cannot be punished (impunity). The third is the malfunctioning of state institutions which authorized and obliged to uphold human rights. Finally, the current attitude a personal goal from individual actors or groups who want to take advantage of conflicts that occur to benefit.

Second, According to Van Meter and Van Horn [8] Implementation are actions taken either by individuals,officials, or groups of government or private that are directed at the achievement of the objectives outlined in the policy decision. Based on the understanding of the above understanding that implementation is a process or an effort made to achieve certain goals, the implementation of fulfilling human rights as an effort to strengthen Positive Peace is a step taken to realize positive peace, peace without any violations of human rights both individuals and groups.

Third, Frameworks, and develop and empower human rights institutions. As well as community participation to be aware of the spirit of humanity in protecting others in the midst of the barbarity of the times 


\section{B. Suggestions}

1. Effortsto prevent early social conflict need to be done. Regional Governments must be more responsive in conflict management efforts that have not yet occurred or that have already occurred. Local government must pay more attention to the opportunities of conflict in the region and be able to map conflict-prone areas. The motivation of the apparatus is crucial in the timeliness of providing excellent service, to the personal approach by the leadership needs to be done wisely for employee motivation can be further increased.

2. In the future, to increase discipline, the leadership should apply strict sanctions for all employees who are not disciplined according to Government Regulation No. 53 of 2010 concerning the Discipline of Civil Servants and provide rewards for employees.Second, conflict mapping can help graphically illustrate conflict which is useful for seeing the overall conflict actors and their relationships. In a conflict that becomes the main focus are two parties who act as the main actors who contradict each other. In short, the main objectives of mapping conflict are to understand the situation better, to see the relationships between various parties clearly, to explain where power lies, and evaluate the actions that have been carried out by each conflict actor.

3. Third, it is necessary to formulate a system of continuous monitoring of the regions and communities, which are prone to conflicts. So that in carrying out social life from conflict.

\section{REFERENCES}

[1] zamroni, Peace Education. A Reader. .

[2] S. M. Habibah, "Penanaman Nilai-nilai Multikulturalisme pada Sekolah Background Agama," Integralistik, vol. 2/Th.XXVI, 2017.

[3] S. M. Habibah, "Penguatan perlindungan perempuan dan anak dalam upaya mempertahankan indonesia yang bermartabat melalui tanggung jawab," in revitalisasi kearifan lokal untuk membangun martabat bangsa, Surabaya: University press, 2016, p. 1.

[4] Y. R. C. . Gaol, "Radio Kumintas: Alternatif Media Berbasis Lokal Untuk Membangun Perdamaian," in Wajah Damai Negeriku, Yogyakarta: Baskara Media, 2018, p. 133.

[5] I. M. Windhu, Kekuasaan dan kekerasan menurut Johan Galtung. Yogyakarta: Kanisius, 1992.

[6] D. P. Barash, Aproach to Peace: A Reader in Peace Studies. Newyork: Oxford University Press, 2000.

[7] A. Nurcholis, Peace Education Dan Pendidikan Perdamaian Gus Dur. PT Alex MediaKomputido, 2015.

[8] A. S. Wahab, Analisis Kebijaksaan dari formulasi ke implementasi kebijaksanaan negara. 2008. 